\title{
GRASPING THE NETTLE - THE TASMANIAN GEOLOGICAL SURVEY'S WORK ON LANDSLIDES, 1971-1988
}

\author{
by Peter Charles Stevenson
}

(with four text-figures and five plates)

Stevenson, P.C. 2011 (9:xii): Grasping the nettle - the Tasmanian Geological Survey's work on landslides, 1971-1988. Papers and Proceedings of the Royal Society of Tasmania 1 45:39-50. https://doi.org/10.26749/rstpp.145.39 ISSN 0080-4703.

135/319 Macquarie Street, South Hobart, Tasmania 7004, Australia. Email: psteve135@gmail.com

\begin{abstract}
The state of Tasmania had suffered from its foundation from landslides. A policy of limited compensation for property loss had been established in the 1960s as insurance was not available but landslide damage had continued and the compensatory policy had to be abandoned. The Tasmanian Geological Survey worked on this problem mainly in Northern Tasmania and devised a system of advisory zone maps to control building development, followed by legislative controls. Some comments are made on the social impact of these measures. The period from 1971 to 1988 is described as being the main period of innovation. A selection of the originating reports is referenced, and a site for the whole corpus is given.
\end{abstract}

Key Words: landslip, landslide, legislation, Tasmania, Tasmanian Geological Survey.

\section{INTRODUCTION}

Landslides are a recognised problem throughout Tasmania. Some parts of the state are particularly vulnerable, and amelioration of such risk came under the purview of the Engineering Geology Section of the Geological Survey of Tasmania. During the period 1971-1988, a coordinated effort to reveal the causes of landsliding and to devise a strategy to counter them, was instigated by the government of the day under the leadership of the Premier, the Hon. Eric Reece, in response to considerable loss of houses in the preceding years.

This paper records that work, the vast majority of which was undertaken in the areas of immediate need, notably the Tamar Valley and the North-West Coast of Tasmania.

The approach was based firstly on the geology as revealed by regional mapping, then on geomorphology and on a study of the clay materials involved as revealed by soil mechanics. The structures of slides were sometimes elucidated by geophysical means. A landslide-risk-class system was then set up and together with resulting maps and finally legislative additions to the Local Government Act 1962 control could be exercised over building development.

Development of the system involved face-to-face discussion with members of the public and with local government councils. This approach was valuable in that it removed the usual criticism that public servants were making decisions affecting the public without having shown that the basic research had been done. It also served as a strict check on the work in the field done by the Geological Survey officers.

\section{GEOLOGY}

The surface geology was available from the regional mapping of the Launceston (Longman et al. 1964), Pipers River (Marshall et al. 1965), Beaconsfield (Gee \& Legge 1971), Devonport (Burns 1963), Burnie (Gee etal. 1977) and Table Cape (Gee 1966) sheets of the Geological Atlas One Mile Series issued by the Department of Mines. These indicated the presence of Tertiary sediments known to be involved in landsliding, as well as the presence of Tertiary basalt that was often implicated, either as a triggering aquifer or in weathered condition as actively sliding material (Blake 1961, Jennings 1964a) (pl. 1).

The stratigraphic and lithologic relations within the Tertiary sediments of mainland Tasmania were not known in any detail (see Burrett \& Martin 1989) and appear to remain so to this day, owing to their complexity, and their labile nature, leading to a very poor outcrop expression. This property did not disadvantage the geomorphic studies as each landslide exposure had to be treated as a unit without other than a general reference to other occurrences. The labile clay sequences were those involved in landsliding, while the gravelly or sandy members were not, except as intercalated aquifers.

\section{THE NATURE OF LANDSLIDES}

The terms landslip and landslide are synonymous, the former being English practice and the latter American. The latter is preferred here as a "slip" appears to imply a minor feature which may nevertheless have serious consequences.

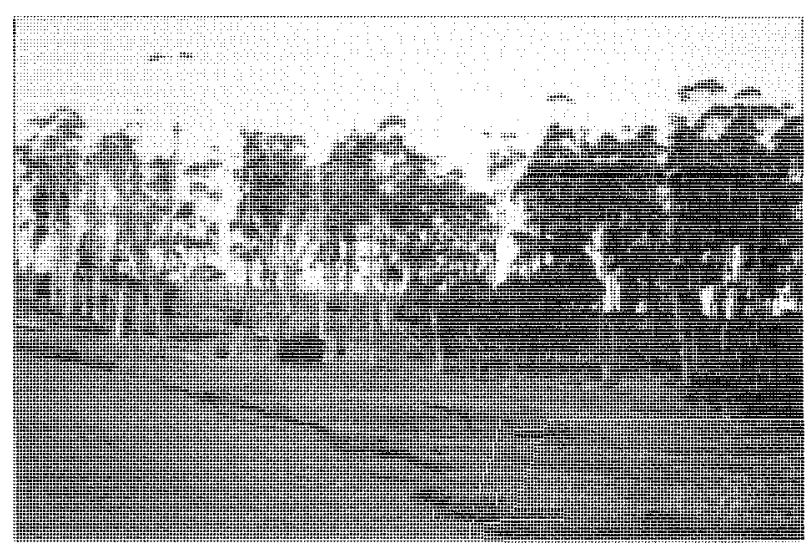

PLATE 1

The Batman Slide $\left(41.21^{\circ} \mathrm{S} ; 146.92^{\circ} \mathrm{E}\right)$ in Tertiary clays, water being fed from overlying Tertiary basalt. 
The phenomenon had been extensively covered in the literature, but the works of Zaruba \& Mencl (1969) and of Schuster \& Krizek (1978) are conspicuous. The publications of Chowdhury (1978) and Walker \& Fell (1987) are also notable and reptesent an extensive literature. All these works indicate the terms employed in description of materials, of geometry, of climatic setting and of all types of slope movement. Recognition of movement and the details of field investigation, the measurement of strength properties and methods of stability analysis are all covered in detail, with many relevant examples. This background will be assumed in the present account.

The Tasmania landslides are characterised by slow movement, usually no more than one metre per month, on slopes as little as $6^{\circ}$ rising to as much as $1^{\circ}$, and are described as slow earthflows. Rotational slides are only seen in early stages of movement, but these develop into translational slides. Collectively these may be called slump earthflows. They have been described as "slow disasters" by householders whose property is threatened or destroyed.

\section{PREVIOUS WORK}

The earliest work on landslides in Tasmania appears to be that of Friend (1849), and dealt directly with the problem, rather than merely mentioning landslides as a peripheral topic. Friend's appreciation of the problem has a remarkably modern look, and one would wish to know more of this naval officer and Fellow of the Royal Society, who subsequently became Port Officer in Hobart (Hobart Town Gazette 1838).

Friend recognised that cultivation of steeper slopes and removal of trees might lead to instability (pl. 2), that the opening of fissures would increase the access of water to the slide plane, that downward movement of the slide mass would cause the toe area to rise up, and that control might be established by judicious drainage of the land above the slide.

Ingles (1974) described the Australian incidence of landsliding, and gave some account of Tasmanian examples, but other local accounts such as Johnston $(1874,1888)$, Carey (1946) and Kershaw $(1955,1958)$ have very little to say on the subject. Johnston uses the term "wanton unconformity" ambiguously when describing the Tertiary sediments of Windmill Hill and did not make clear whether the term applied stratigraphically or to the outcrop pattern.

When we turn to Geological Survey records, the field is much richer, but this was the result of more or less ad hoc studies occasioned by separate events until 1971, when the systematic studies which are the core of this paper began. All reports by the Tasmanian Geological Survey are available online from the Mineral Resources Tasmania (MRT) website (www.mrt.tas.gov.au) using the "Document Search" facility with the keywords landslip, landslip zone map, landslip active and dormant landslip.

Nye (1931a, b, c) was concerned with Groom's Slip and the Lonah Slip (fig. 1). These are located on the coast between Penguin and Ulverstone. Groom's Slip reappears several times in the records and as a persistent phenomenon will continue to do so. Nye related how there had been movements of Groom's Slip "28 years ago" and that draining work was done until defeated by "slurry". It seems likely that this landslide has afflicted transport movement in the area for much of the European settled life of Tasmania. Because it affects the railway as well as the road it attracts close attention (pl. 3). Nye showed that the landslide is

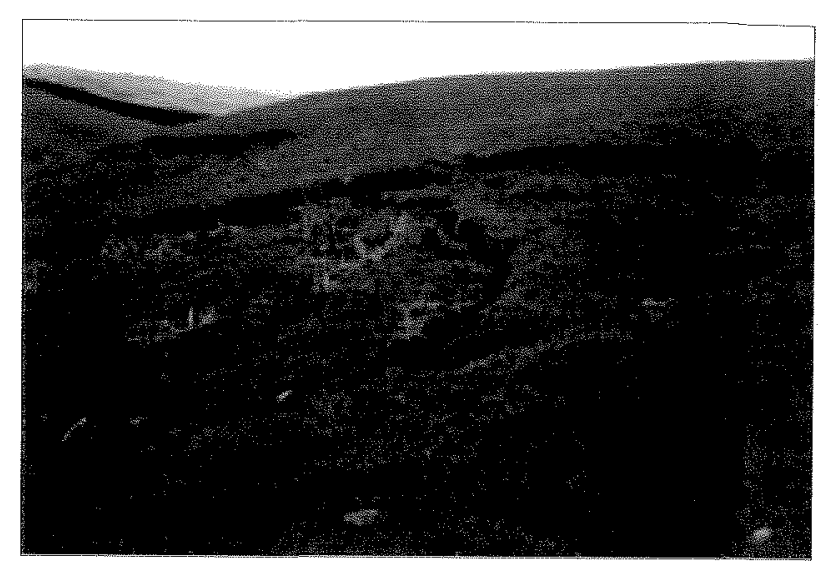

\section{PLATE 2}

Incipient Head Scarps in a new slide at White Hills (41.53\% $147.26^{\circ} \mathrm{E}$ ).

translational and moves on a dolerite (sic) planar surface, with some accumulation at the toe. As this is just above sea level, instability is maintained by the constant erosion of the toe by the waves. A sand layer was implicated as the source of water which drove the movement, and that the use of drains would have to wait until movement stopped.

Blake (1958) had to deal with a landslide away from the principal locus of concern. The slide at Bream Creek had interrupted a rural road over many years and consisted of basalt-derived slope deposit, and was driven by springs issuing from the basalt upslope. Drainage or diversion of the road was suggested.

Burns (1957) considered unstable slopes at Kelcey Tier near Spreyton (fig. 1), again away from the Tamar and the North-West Coast. These posed a potential threat to the projected water pipelines. Burns considered the geology in

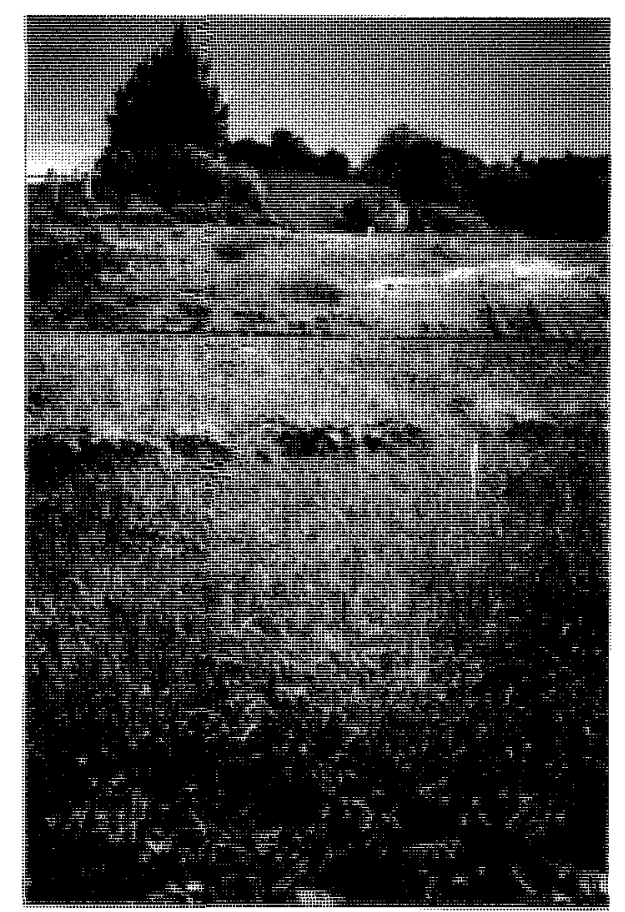

PLATE 3

Groom's Slip $\left(41.12^{\circ} \mathrm{S} ; 146.11^{\circ} \mathrm{E}\right)$ : view from the toe looking up the slip. The railway and road are shown crossing the slip. 


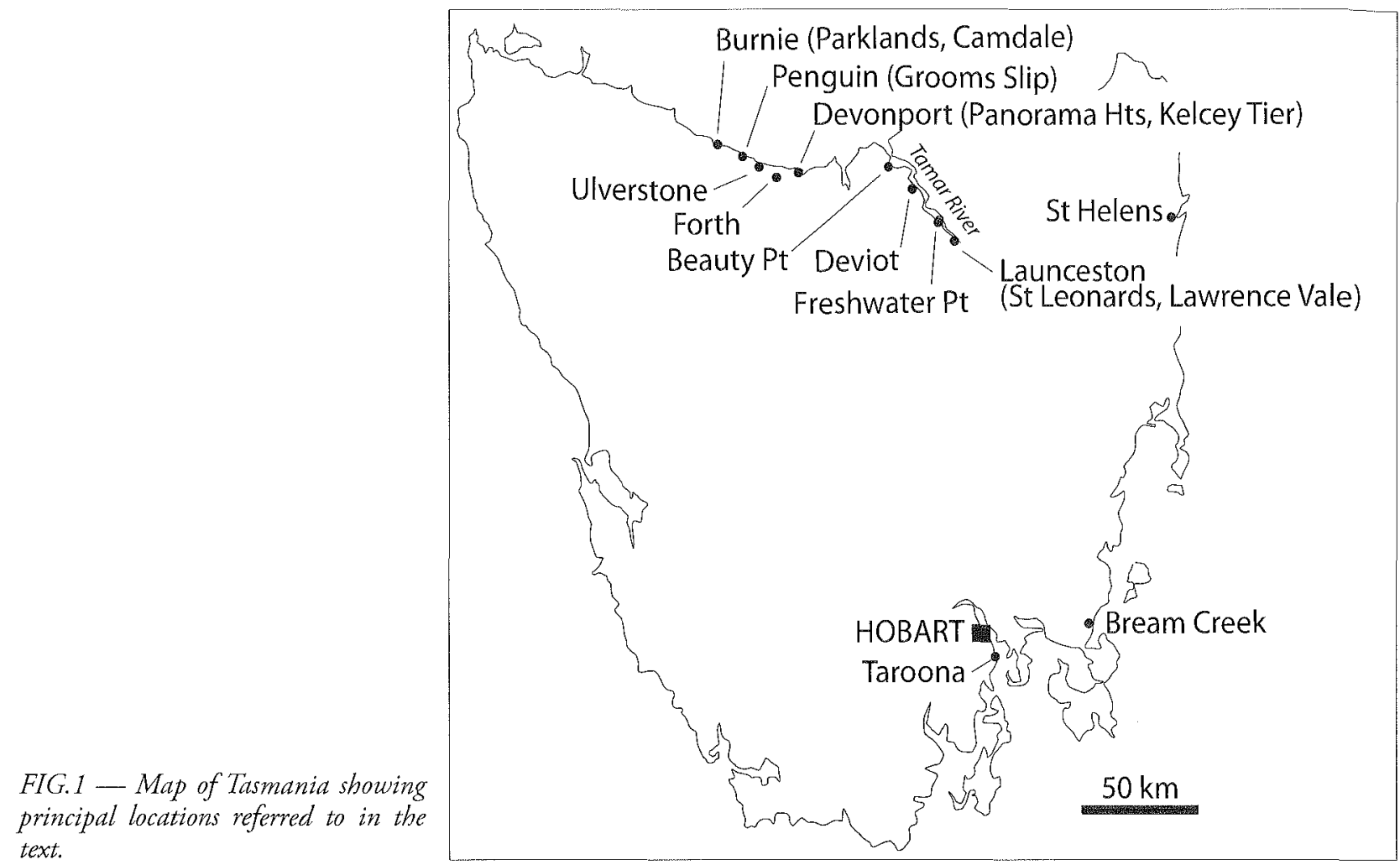

some detail; then, when looking at the stability of the slopes, found that geomorphology provided the most useful guide. He recognised four types of instability, and provided most useful analyses that became of importance in subsequent investigations.

Burns (1959) dealt with pipeline routes again in northern Tasmania and commented on unstable slopes, then Hughes (1959) described landslides at Burnic (fig. 1) in basaltderived soils, and pointed to increased access of water to the site from development activities as being the precipitating factor. He recommended that surface drains be lined and that councils should exercise caution in granting subdivision permission on the slopes of basalt hills.

Blake (1961) examined the landslides of longstanding at Beauty Point (fig. 1) and showed that the presence of a basalt aquifer overlying plastic clay is a recipe for instability that is later revealed as very common. He mapped active sliding and suggested drainage of a swamp formed in a slide-caused reversal of slope.

Hughes (1960), in a report on a meeting held in Launceston Town Hall in relation to the Lawrence Vale Landslip (fig. 1), revealed that it was the site of the destruction of a number of houses in the 1950s. Dr G. Aitchison of the CSIRO and Mr E. Gill of the Victorian Museum were present. This expert intervention had been arranged by Prof. Sam Carey and was to consider the conduct and costs of a general survey of the parts of Launceston underlain by Tertiary sediments. The meeting was abortive as the costs were considered too high, no further work was done and the project was abandoned.

Jennings (1962) re-examined instability at Parklands, Burnie, and incorporated the work of Burns \&. Gee (1962). Landsliding had destroyed an urban street, disrupted water supply, drainage and communication services, as well as blocked the Bass Highway. Causes were numerous including the usual abundance of uncontrolled access of water to the site, deficient drainage, construction works loading the slope and trenches acting as recharge areas. Disruption of roads was of major concern as illustrated in plate 4 .

Jennings (1964a) took up the tale of Beauty Point instability, and enlarged on the work of Blake. He provided maps of the geomorphology, suggested restricted areas for building and recognised that unwise development is a contributing cause of instability. Controls on subdivision were required. Jennings (1964b) made detailed recommendations, and a general review was attempted of slope problems in the Burnie area. This report is seminal, and forms a foundation for much of the subsequent landslide work in Tasmania.

Matthews (1964a, b) and Jennings (1964b), working on the North-West Coast, must be credited with the concept of zones drawn on maps to limit development in landslide-

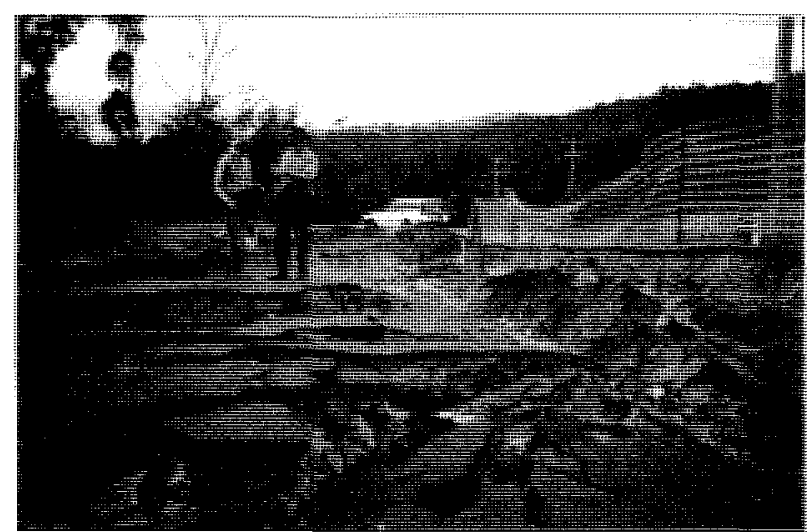

PLATE 4

Pleasant Hills $\left(41.36^{\circ} \mathrm{S} ; 147.01^{\circ} \mathrm{E}\right)$ showing the disrupted road surface toward the toe area in Tertiary clays. 
prone areas on the basis of geology, geomorphology and slope. This concept was adopted and extended during the succeeding systematic survey. Jennings (1969a) then returned to Beauty Point, and suggested precautions to be observed by the council, in the siting of houses, and the installation of more effective drains.

Stevenson (1969) described a mud spring and a landslide at Deviot (fig. 1). The spring showed the behaviour of groundwater where water-filled gravels and clay horizons are in contact, and the landslide in similar geology nearby showed the disruptive effects of excess groundwater in sensitive conditions. The shape of the slide and the effects of drying, wetting and shrinkage on the exposed clays were described, and the remarkably low angle of slope to induce movement was indicated.

Jennings (1969b) visited the Lawrence Vale Landslip Area which was the subject of the Lawrence Vale Landslip Act 1961. He described the tension cracks in the landslide as being water-filled, and stated that other houses were threatened. He considered that the landslide might extend northward (Jennings $1969 \mathrm{~b}$ ). He recommended the installation of herringbone counterfort drains, and that a close eye be kept on further movements. Jennings \& Stevenson (1969) expanded on this report and revealed further details of the geology. Actual movement was seen in opened trenches, and the landslide was seen to be purely translational. The drainage and support measures being taken were confirmed.

Stevenson (1971b) described some zoning at Camdale and added some thoughts on how to go about a decision on land stability. Stevenson (1972c) investigated the 1969 reactivation of the landslide at Beauty Point, which resulted in 12 houses and a police station being destroyed, demolished or removed due to extensive damage, and Jennings (1972) investigated the major landslide problems developing in Tertiary sediments at Parnella, near St Helens (fig. 1).

These studies provided the background on which the Engineering Geology Section began its systematic study of landslides and was used to guide the systematic study.

The Government had provided some compensation for landslide loss by the Lawrence Vale Act 1961, the Beauty Point Act 1970, and subsequent extensions. Even though landslide risk is uninsurable, this approach could not continue as more and more landslide hazards were revealed.

The study was therefore authorised by the Premier of the day, the Hon. Eric Reece who was also the Minister of Mines. I have been unable to find a written instruction, but was present when $\mathrm{Mr}$ Reece, inspecting the landslides at Freshwater Point on 16 March 1972, said that "we must grasp the nettle".

\section{THE SYSTEMATIC SURVEY}

Some 800 landslides of various sizes and activity had been recognised in the Tamar Valley, and a similar number on the North-West Coast, though an inventory of individual landslides was not compiled. It was therefore with a wholesale "walkover" of the Valley and of the Coast that the study began. All geologists in the team had to become familiar with the examples previously described and as new geologists joined the work they were expected to take this tour. The various skills of the Engineering Geology Section provided an augmentation of techniques utilised as the survey developed; for example, the addition of soil mechanics, test pits, geophysics and stability analyses.
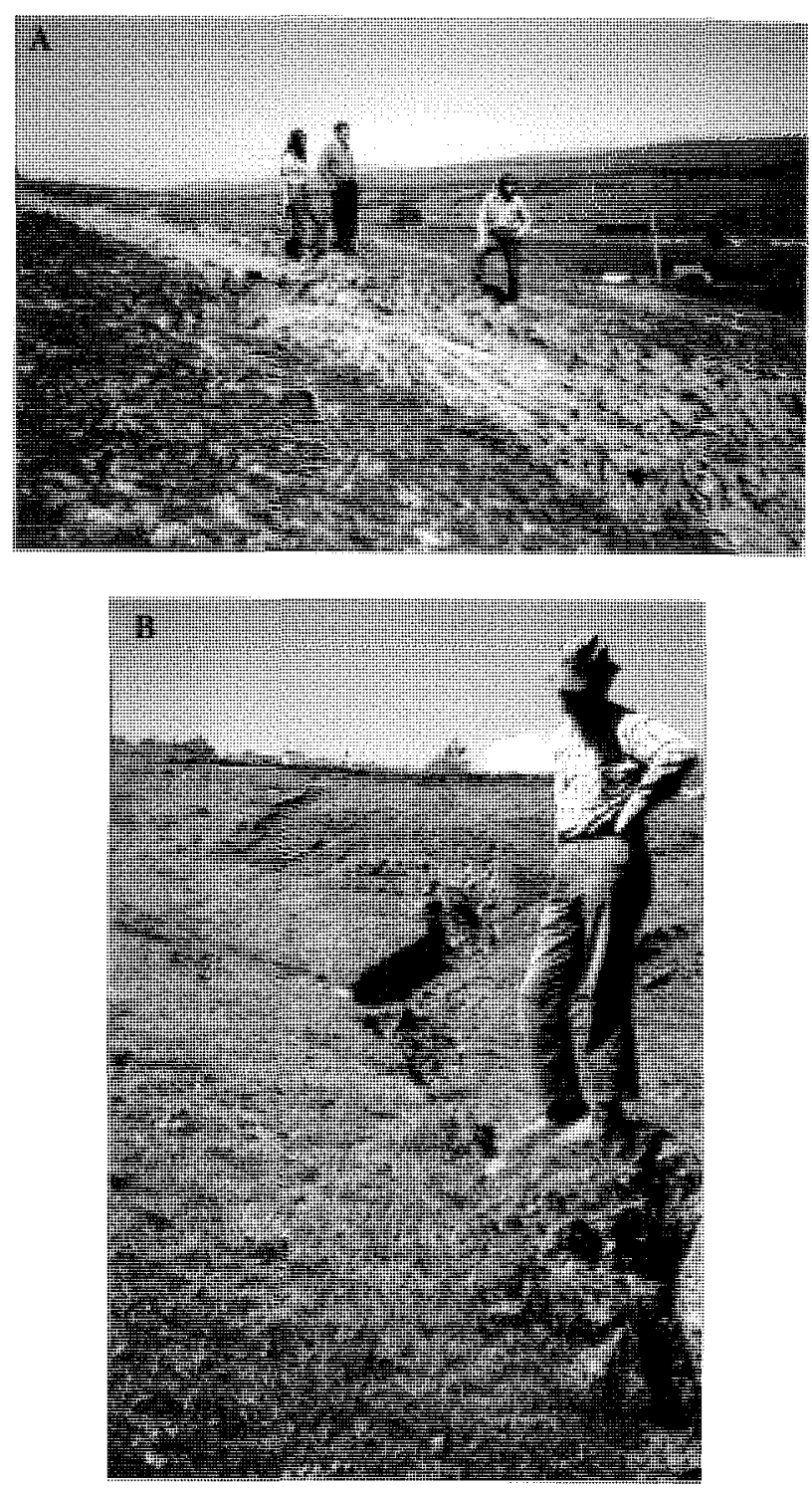

PLATE 5

A, B. Two views of Side Shear of the St Leonards Slide $\left(41.45^{\circ} \mathrm{S} ; 147.21^{\circ} \mathrm{E}\right)$.

The 22 examples that follow are a selection from 221 that became technical reports and unpublished reports within the Survey. They are chosen to outline the methods that became the genesis of the Landslide Risk System, and the total number is available online at www.mrt.tas.gov.au

As the number of the reports rose (they totalled nearly 300), further specific public enquiries were dealt with by individual correspondence, and are not quoted here, but are recorded in the CARS database, a correspondence database held by MRT.

Stevenson (1971a) was concerned with a proposed subdivision near Penguin. The geology was examined and revealed that a grey clay horizon is present underlying basalt which caps the slope. This situation was described as "well known in basalt areas in Northern Tasmania", and was further revealed by four trial pits excavated by backhoe. It was concluded that the grey clay poses a minor hazard to road construction, but that subdivision and the introduction of additional water could produce more extensive failure 
of the hill slope. Some restriction of subdivision and care in the development of the remainder was recommended.

Elmer (1971) at Freshwater Point, in the middle Tamar, showed that small landslides had already occurred, and recommended that trial pits should be opened in an attempt to reduce the suspect area, but in general houses should be restricted to the flatter areas away from the crest of the slope. Stevenson (1972a) then described a landslide that was threatening two large water storage tanks of the Tamar Water Supply at St Leonards, outside Launceston (fig. 1, pl. 5A, B). The landslide was first reported in 1968 and the current study was a visit to determine the state of the slide. It appeared to have formed as a result of leakage from a valve pit close to the tanks, but on this occasion it showed signs that it had stabilised, desiccated and then several wet seasons had remobilised and extended it. In addition, it had eaten upslope closer to the base of the tanks. Remedial stonefilled drains had been disrupted by the further movements, and the planting of high transpiration trees was suggested.

Stevenson (1972b) provided the latest of three reports on a subdivision at Panorama Heights, Devonport (fig. 1). This report was supported by soil mechanics tests conducted by the Public Works Department (Kowaluk 1972 as an appendix to this report). Here, a significant step in investigation was taken with the use of calculated stability analysis. A pessimistic view as to the viability of the subdivision was the conclusion, and subsequently Landslip Zones were proclaimed.

Matthews (1972) reported on an adjacent subdivision, but with markedly different geology, and as determined from some 15 test pits, most of the area was assessed as suitable for subdivision after drainage and siting precautions were taken.

Stevenson (1974) re-examined Groom's Slip. Seismic refraction, proline auger drilling and soil mechanics, and the installation of piezometers were recommended, whilst Matthews (1974) continued the series of reports on the landslip at St Leonards.

Leaman (1974) summarised geophysical methods appropriate to landslide studies and gave some examples. This enlarged the detail available on some difficult slides.

Knights (1975) provided a detailed soil mechanics study of typical Tamar clays. Atterberg limits, strength sensitivities and X-ray diffraction studies enlightened work on specific occurrences elsewhere. Knights \& Matthews (1977) then produced a report that constituted a major advance, occasioned by another reactivation of the movement at $\mathrm{St}$ Leonards. Detailed topography, drilling of some 27 holes for the location of water-bearing horizons, the installation of movement detectors in the boreholes, the determination of soil mechanics parameters and clay mineralogy, a study of groundwater chemistry, and an evaluation of geophysical methods were all included. A Bishop slope analysis was atternpted, and recommendations for remedy were made.

The report of Donaldson (1977) opened a new field of investigation at Taroona, a suburb of Hobart, outlining a large, very slow moving slide involving the main road, the primary school, the high school and numerous dwellings.

Knights (1977a) continued work in the Tamar Valley using stability analysis to show "very tenuous" stability in movement at McEwan's Road, Tamar. She also re-examined the Lawrence Vale landslide, employing seismic refraction and drilling, and showing the presence of a pressure aquifer (Knights 1977b). Recommendations included tree planting and the installation of additional counterfort drains.
Knights (1977c) provided a piezometric study of aquifers and related clays over an extended period of wet and dry seasons at Lawrence Vale.

In the light of previous investigations, guidelines were offered for studies in stability and swelling soil conditions by Stevenson (1978a). Stevenson (1978b) further provided a work-in-progress report showing the current methods. This report encapsulated the entire philosophy for risk zoning, and drove the work which is the subject of the present paper. Details were given of the construction of the zones and comments on confrontations with objectors were offered. Stevenson (1978c) extended definitions of the Risk Zones were offered to clarify some doubts.

Sloane (1.979) re-examined neglected failures in Tertiary sediments at St Helens. Although known before, this became a new area of investigation. Drainage, vegetation and marine erosion protection works were suggested.

A period of little innovation followed: reporting was largely confined to correspondence as mentioned in the CARS database, but work continued unabated. For example, Moon (1984a) described the use of a hand calculator to perform Bishop analysis and gave the code for it. This gives an idea of the sophistication of calculation methods of the time. Moon (1984b) provided a new consideration of the conduct of slope stability assessments whilst Weldon (1987) gave an account of a Bishop slip circle analysis programmed on a micro-computer. Again this is a comment on the methods of the time.

These selected reports indicate the evolution of methods, and include trial pits, soil mechanics sampling, piezometer installation and recording, slide plane depth determination by various means, geophysical surveys including resistivity, seismic refraction, induced vibration for additional data, slide movement measurement by repeated survey and movement monitors, and calculated stability analysis

\section{THE EVOLUTION OF THE RISK MAPS}

It should be admitted that the term "risk" in this context is a misnomer and should in modern practice be denoted "susceptibility". These maps do not include a concept of frequency or temporal likelihood so are not true "hazard" maps in the modern use of the term. However, the term "risk" is so entrenched in the use of these maps that it will be retained in this paper.

In the light of the experience detailed above it was an easy decision to adopt this system. Five zones were set up (Stevenson 1975a), applicable to the Tamar Valley (figs 2, $3)$. Other areas were not comprehensively covered in this way but the concept was used widely. The five zones were :

Zone I-Stable ground on hard rocks. No abnormal problems or risks. This zone was generally on dolerite;

Zone 2--Stable ground but on soft rocks. Strict adherence to existing building code. This zone was generally on Alluvium or on Tertiary sediments of little topographic expression; with slopes less than $6^{\circ}$.

Zone 3-Potential landslip areas. Building methods in accordance with special building regulations. This zone was generally on Tertiary sediments or related slope deposits having a ground slope greater than $6^{\circ}$;

Zone 4-Old landslips and adjacent areas. No building permitted pending further studies; and

Zone 5-Active landslip. No building permitted.

Many clarifying comments were appended to these 


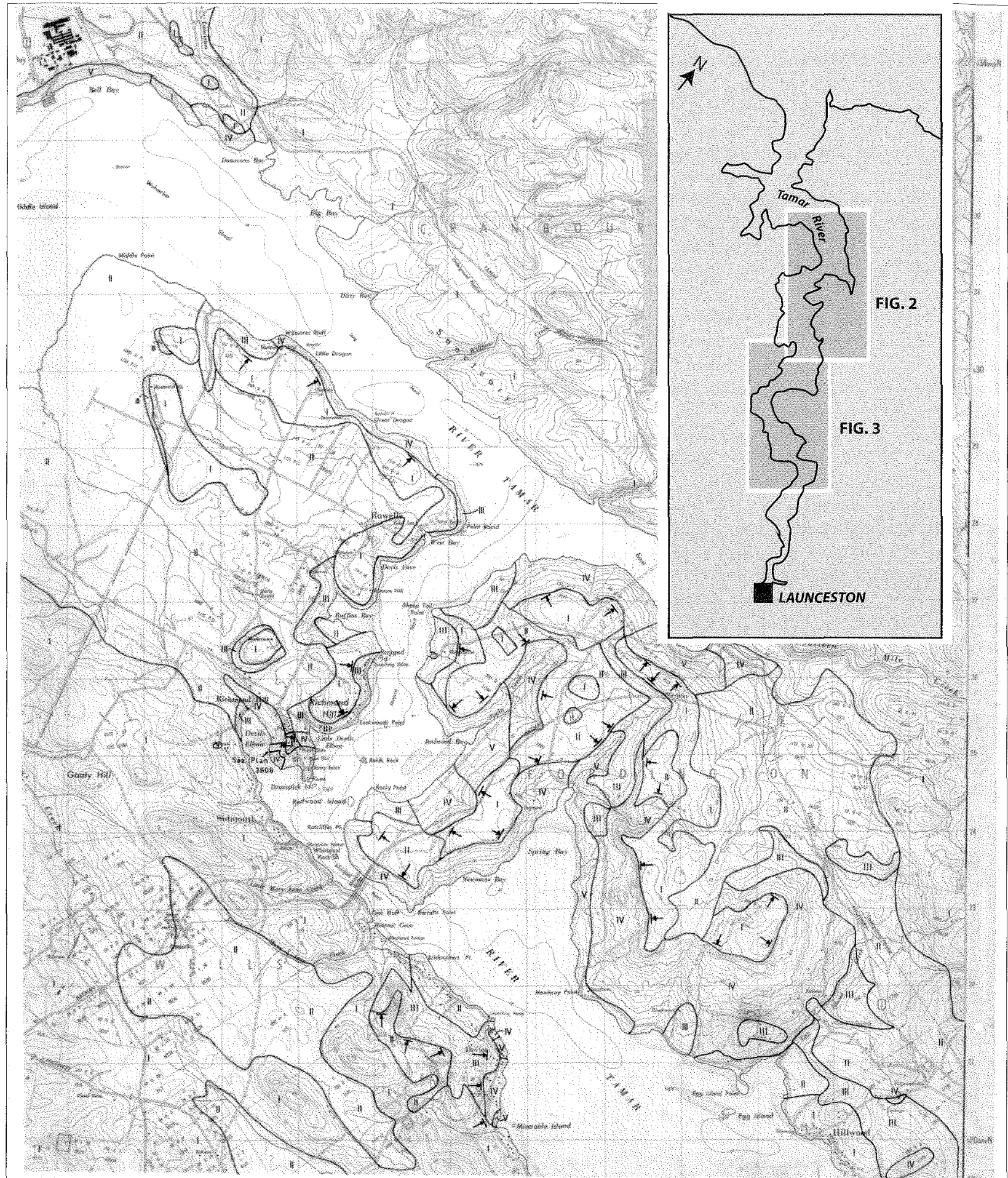

FIG. 2 - The Tamar River valley showing risk zones. Risk zones: V, Active landslips and adjacent areas. No building without specialised investigation and design. IV, Old landslips and adjacent areas. No building without specialised investigation and design. III. Potential landslip areas. Building methods in accordance with a special code. II, Stable ground but on soft rocks. Strict adherence to existing building code. I. Stable ground on hard areas. No abnormal problems or risks. 


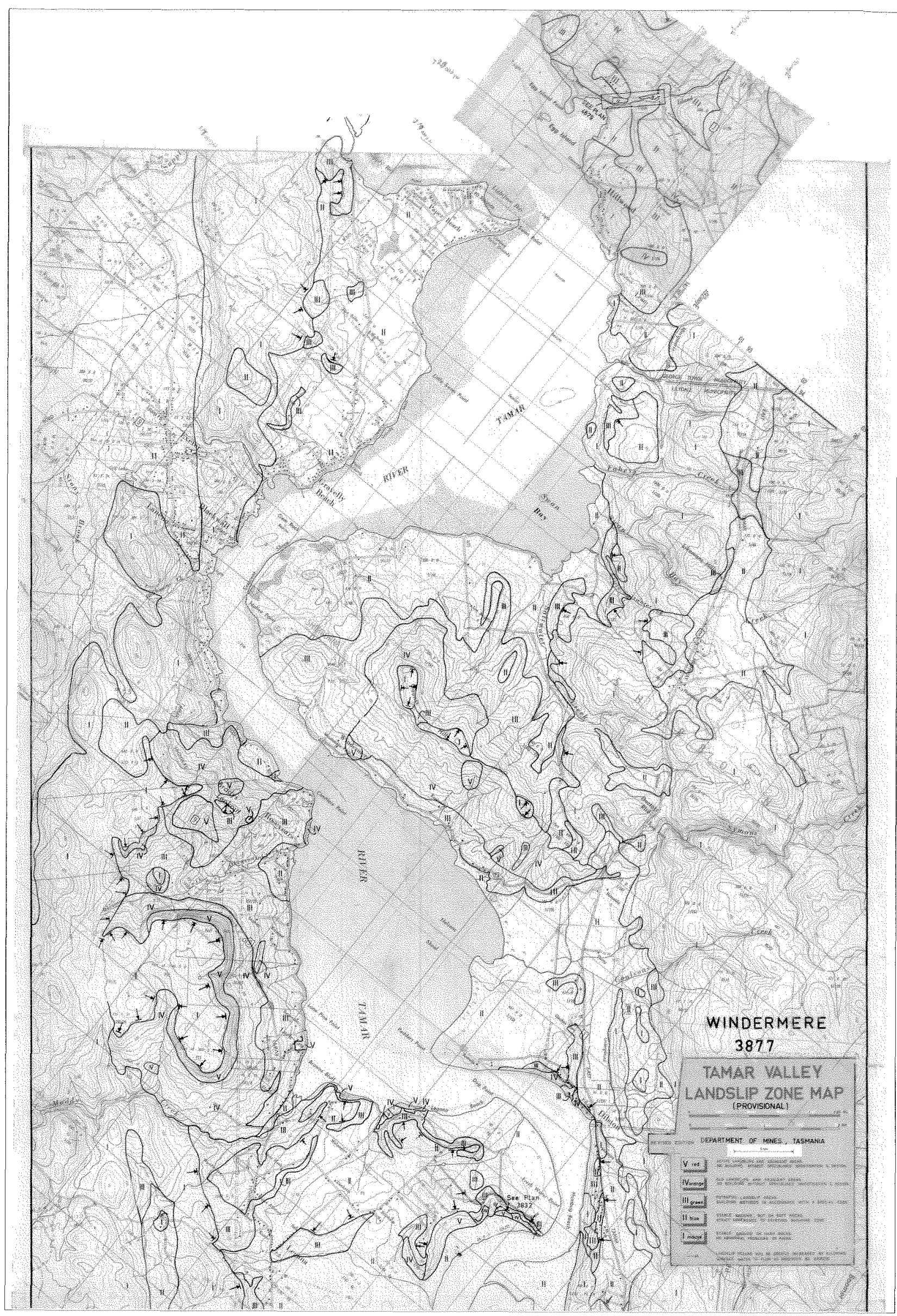

FIG. 3 - The Tamar River valley showing risk zones. Key and location map as for figure 2. 
definitions. One became of major significance. The word "potential" was used by real estate agents as a laudatory term, as in "this land has great potential", whereas in our context it was pejorative, and caused confusion.

These zones were depicted on maps at the scale of four inches to the mile $(1: 15840)$ as these were the best available, and reproduced as dyelines (figs 2, 3), and were freely available on request. Though crude, these maps served for many years, summarising the findings of the detailed field investigations, and they formed a basis for detailed discussions with councils and members of the public. There was a risk of the maps being over-interpreted, but the scale was such that this did not occur often, and the risk was obviated by the usual field visit of the geologist, when features on the ground were pointed out. The Survey provided a consultant service to councils, authorities and the public, at first without cost, but subsequently at a nominal cost.

The landslide maps produced by the Geological Survey were used by some authorities and interested parties in an informal process to prompt interpretation by a Survey geologist and usually a site inspection. There was no legislative requirement for these advisory maps to be considered in the planning process.
Because the Tamar Valley was under constant reexamination, mistakes were readily noticed. Such cases were very few and minor, a tribute to the accuracy of the initial appreciation of the problem. The same remarks can be applied to the maps of the North-West Coast.

\section{THE CHANGES TOTHE LOCAL GOVERNMENT ACT}

The Government had provided some protection from landslide loss by the Lawrence Vale Act 1961, and the Beauty Point Act 1970, with subsequent extensions. As has been indicated, this compensatory approach could not continue as more and more landslide hazards were revealed.

In order to give teeth to the application of restrictions implied in the Zone definitions, an amendment (Section 431A) to the Local Government Act 1962 was brought in which empowered the Director of Mines to recommend the proclamation of zones where special conditions of building would apply. These were called "A" and "B" Landslip Areas and were prescriptive as opposed to the mapped Risk Zones which were advisory (fig. 4).

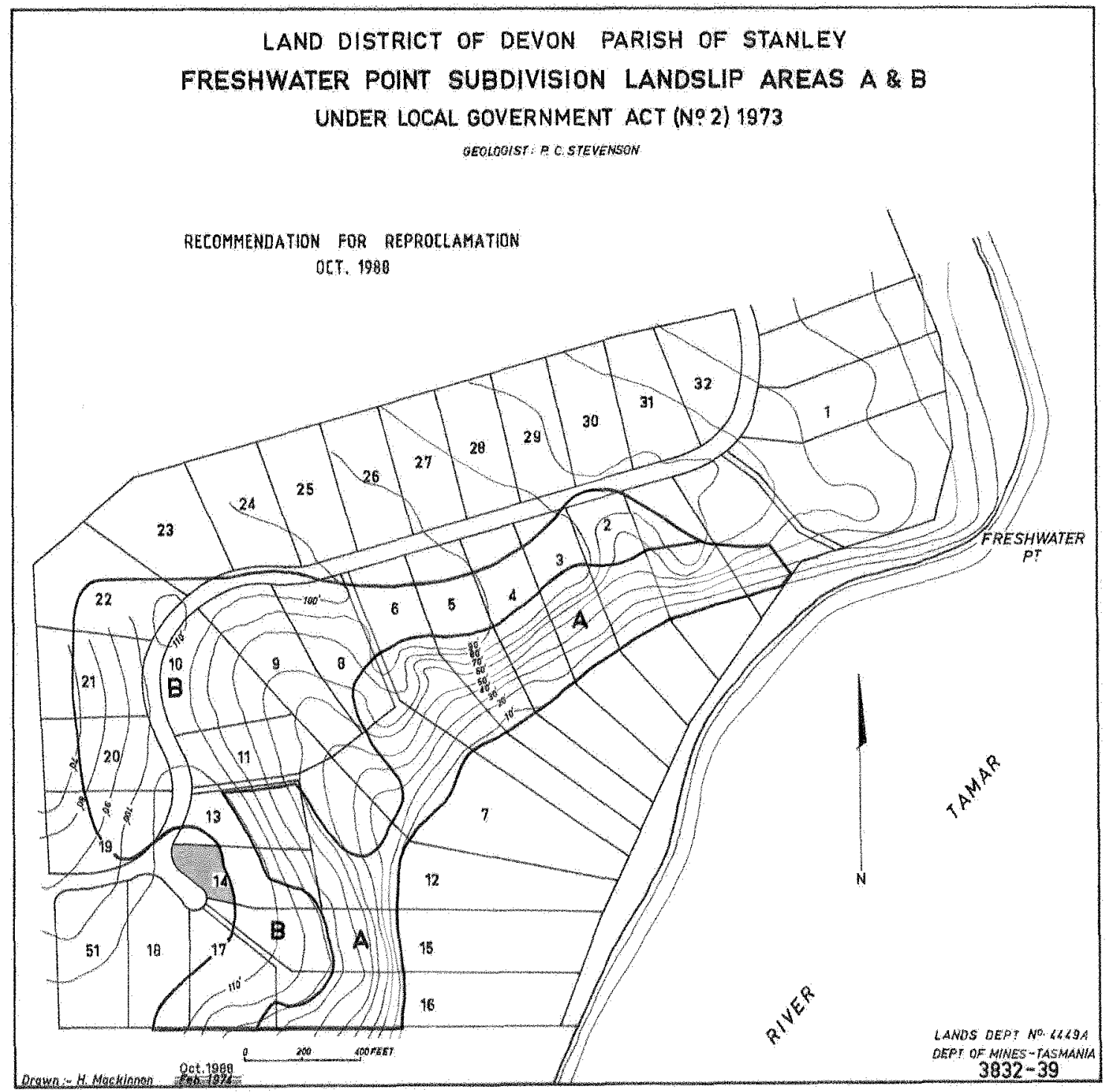

FIG. 4 - Freshwater Point Subdivision, Landslip areas $A$ and B. 
Landslip "A" areas were broadly areas where landsliding was apparent, and adjacent areas into which the slide could, in the opinion of the geologist, extend. Landslip " $B$ " areas were those where a threat of movement was thought to exist, but the threat could be reduced by suitable building methods. Landslip " $\mathrm{B}$ " areas also served the purpose of buffer zones to the Landslip "A" areas, so as to prevent inappropriate practices in the Landslip " $B$ " area affecting the stability of the Landslip " $A$ " area. There was some correlation with the 5 and 4 Zones of the risk maps, but this was not explicit, having been arrived at independenrly. These proclaimed Landslip Areas were defined by a map.

These provisions of the Local Government Act 1971 were subsequently amended and expanded in the Local Government Act (No2) No 96, 1973.

This sanction was used very sparingly and only in desperate cases, for reasons which may best be described as political. Situations did arise, where a landowner would insist on going ahead with a building, often with the comment that "if the building is destroyed then I will accept the loss". This could not be countenanced as the property could subsequently be sold and the later purchaser would not know of the risk involved.

The Special Building Regulations were promulgated as Statutory Rules 1974, No 291, Building Amendment Regulations (No5) 1974. These controlled building in "B" landslip areas.

Broadly the regulations limited the type of building, the floor area, specified drainage practice, limited excavations, controlled filling and compaction, and demanded certificates from practising engineers or engineering geologists as to the soundness of the development.

\section{THE ADMINISTRATION OF THE SYSTEM}

The production of the Risk Maps and rhe provisions of the Local Government Act 1961 as amended caused some disquiet amongst authorities, in the newspapers and amongst the public. It rhen became the task of the Survey team to face the music and be subjected to questioning by councils and members of the public, who often described themselves as "concerned citizens". This was a salutary experience for the geologists, but had two advantages. It was a strict discipline on the geologists involved, and it enabled the geologists to show by their intimate knowledge that they had closely examined the landslide event. It would often disarm criticism if the geologist could show that he had seen a distinctive tree at the property, or had encountered a distinctive dog.

$A$ visit to the site was often arranged when the geologist could demonstrate the geomorphic features of the slide, and relate them to the damage to house or road, and could possibly comment on the faulty drainage. The wide experience afforded by the obligatory "tour" on taking up the work was invaluable in these encounters.

Meetings of this kind were remarkable for their cordiality, and the restraint shown by landowners who might be suffering considerable loss. This can only be explained by the knowledge and professionalism shown by the geologists involved.

\section{EXTRANEOUS PUBLICATIONS}

Extraneous publications which arose from the Systematic Survey include 4th AGC (1980) ANZSLIDE87 (1987), Knights \& Matthews (1976), Sloane (1985), and Stevenson (1975b). The contributions to ANZSLIDE87 form a useful summary of the work at this date.

\section{AFTERTHOUGHTS}

Behind the everyday work done by the landslide team there was always a group of questions that could not be confronted, by reason of immediate demands and lack of resource. These questions involved the geological history and lithologic variation of the Tertiary sediments, of the history of the slopes in Tasmania, the effect of weathering on the slide materials, and the age and origins of the presumed causative uplift. It was apparent that there were generations of landslides, the younger often parasitic on the older, together with the implication that only residual strength is retained in the once-moved material.

These matters remain to be examined so that a fuller picture of the landslide phenomenon will appear, affording greater safety to building construction.

The existence of the advisory landslide risk maps, and the independent advice provided by the Geological Survey, produced a climate of careful building development. In practice this does not appear to have been maintained to the present day.

From the very nature of the Systematic Survey, the losses from landsliding that were prevented cannot be determined. It can only be hoped rhat as the housing stock ages, the replacement buildings will be built in places which will not endanger them, and by methods that will improve their survival.

\section{ACKNOWLEDGEMENTS}

I wish to acknowledge the contributions in various fields, beginning with the erstwhile Minister for Mines, the Hon. Eric Reece who grasped the nettle, and changed the ad boc approach to landslides into a systematic survey. I would of course wish to acknowledge the work of the team which at various times was comprised of Richard Donaldson, Sture Elmer, Ian Jennings, who was also Chief Geologist, Carolyn Knights, David Leaman, Lloyd Matthews, Alan Moon, Bert Moore, John Sloane, Andrew Telfer and Barry Weldon, more than ably assisted by technicians Barry Cox and Richie Woolley and surveyor Geoff Benn. I am indebted to Colin Mazengarb and Michael Stevenson, of Mineral Resources Tasmania, for invaluable help and discussions, and to Carol Bacon for encouragement. This paper and illustrations are published with the permission of the Director of Mines. I thank June Pongratz for her drafting.

\section{REFERENCES}

4th AGC 1980: Excursion guide no. B2 - Engineering geology: slope stability on the North West Coast and Tamar Valley. Fourth Australian Geological Convention, Hobart, 14-18 January 1980.

ANZSLIDE87 1987: Excursion guide - Tasmania section (6-7 
August 1987). ANZSLIDE ‘87, Australia \& New Zealand - Fifth International Conference and Field Workshop on Landslides, Christchurch, 11-12 August 1987.

Blake, F. 1958: Landslip at Secondary Road, Bream Creek. Department of Mines, Tasmania, Technical Reports 2: 113-115.

Blake, F. 1961: Landslips at Beauty Point. Department of Mines, Tasmania, Technical Reports 5: 194-196.

Burns, K.L. 1957: Reservoir sites near Kelcey'Tier. Department of Mines, Tasmania, Technical Reports 1: 41-49.

Burns, K.L. 1959: Unstable slopes and the Forth pipeline. Department of Mines, Tasmania, Technical Reports 3: 122-135.

Burns, K.L. 1963: Geological atlas I mile series, Sheet 29 (8115N), Devonport. Department of Mines, Tasmania.

Burns, K.L. \& Gee, R.D. 1962: The Parklands landslide second report. Department of Mines, Tasmania, Unpublished Reports $1962 / 03$

Burrett, C.F. \& Martin, E.L. (eds) 1989: Geology and Mineral Resources of Tasmania. Geological Society of Australia Special Publication 15: 574 pp.

Carey, S.W. 1946: Geology of the Launceston district. Records of the Queen Victoria Museum of Launceston 2(1): 31-46.

Chowdhury, R.N. 1978: Slope Analysis. Elsevier, Amsterdam: $423 \mathrm{pp}$.

Donaldson, R.C. 1977: Road foundation failures, Channel Highway. Department of Mines, Tasmania, Unpublished Report 1977/36.

Elmer, S. 1971: Slope stability at Freshwater Point. Departmen of Mines, Tasmania, Unpublished Report 1971/20.

Friend, M.C. 1849: On the landslips which have recently occurred on the west bank of the River 'Tamar, Van Diemen's Land. Tasmanian Journal of Natural Science 3(5): 358-360.

Gee, R.D. 1966: Geological atlas 1 mile series, Sheet 22 (8016S), Table Cape. Department of Mines, Tasmania.

Gee, R.D., Gulline, A.B. \& Bravo, A.P. 1977: Geological atlas 1 mile series, Sheet $28(8015 N)$, Burnie. Department of Mines, Tasmania.

Gee, R.D. \& Legge, P.J. 1971: Geological atlas 1 mile series, Sheet $30(8215 N)$, Beaconsfield. Department of Mines, Tasmania.

Hobart Town Gazette 1838: 16 February 1838.

Hughes, T.D. 1959: Landslides at Burnie. Department of Mines, Tasmania, Technical Reports 3: 135-136.

Hughes, T.D. 1960: Lawrence Vale Landslip. Department of Mines, Tasmania, Unpublished Reports 1960: 34-35.

Ingles, O.G. 1974: Unstable landforms in Australia. Water Research Foundation of Australia, Report 42.

Jennings, I.B. 1962: Landslips at Parklands, Burnie. Department of Mines, Tasmania, Technical Reports 7: 93-98.

Jennings, I.B. 1964a: Slope stability at Beauty Point. Department of Mines, Tasmania, Technical Reports 8: 92-99.

Jennings, I.B. 1964b: Landslides in the Burnie district. Department of Mines, Tasmania, Technical Reports 8: 107-112.

Jennings, I.B. 1969a: Inspection of proposed subdivisions, Beauty Point. Department of Mines, Tasmania, Technical Reports 14: 77-79.

Jennings, I.B. 1969b: Landslip, Lawrence Vale area, Launceston. Department of Mines, Tasmania, Technical Reports 14: $82-84$.

Jennings, I.B. 1972: Landslips on the northern slopes of Aerodrome Hill, St Helens. Department of Mines, Tasmania, Technical Reports 15: 87-90.

Jennings, I.B. \& Stevenson, P.C. 1969: Further report on a landslip in the Lawrence Vale area. Department of Mines, Tasmania, Technical Reports 14: 84-88.

Johnston, R.M. 1874: Regarding the composition and extent of certain Tertiary beds in and around Launceston. Papers and Proceedings of the Royal Society of Tasmania 1873; 39-47.

Johnston, R.M. 1888: Systematic account of the geology of Tasmania. Government Printer, Hobart: 408 pp.

Kershaw, R.C. 1955: Geological observations on the west Tamar.
Victorian Naturalist 71; 138-144, 153-156, 175-179.

Kershaw, R.C. 1958: Further observations on the geology of the Tamar River. Victorian Naturalist 74: 179-188.

Knights, C.J. 1975: Strength parameters and the progressive failure of hill slopes. Department of Mines, Tasmania, Technical Reports 19: 93-99.

Knights, C.J. 1977a: A landslip investigation on the toe area of an old landslip at McEwans Road, West Tamar. Department of Mines, Tasmania, Unpublished Report 1977/47.

Knights, C.J. 1977b: Investigation of the Lawrence Vale Landslip. Department of Mines, Tasmania, Unpublished Report $1977 / 53$.

Knights, C.J. 1977c: Piezometric measurements in Tertiary lacustrine sediments in the Tamar Valley, Tasmania. Department of Mines, Tasmania, Unpublished Report $1977 / 37$.

Knights, C.J. \& Matthews, W.L. 1976: A landslip study in 'Tertiary sediments, northern Tasmania. Bulletin of the International Association of Engineering Geology 14: 17-22

Knights, C.J. \& Matthews, W.L. 1977: Investigation of a landslip at St Leonards. Department of Mines, Tasmania, Technical Reports 20: 174-218.

Leaman, D.E. 1974: Summary of methods and ideas in landslip geophysics. Department of Mines, Tasmania, Technical Reports 17: 61-64.

Longman, M.J., Matthews, W.L. \& Rowe, S.M. 1964: Geological atlas 1 mile series, Sheet 39 (8315S), Launceston. Department of Mines, Tasmania.

Marshall, B., Barton, C.M., Jennings, D.J. \& Naqvi, I.H. 1965 Geological atlas 1 mile series, Sheet 31 (8315N), Pipers River. Department of Mines, Tasmania.

Matthews, W.L. 1964a: The geology of the Burnie area. Department of Mines, Tasmania, Technical Reports 8: 103-107.

Matthews, W.L. 1964b: Geology of the Penguin area. Department of Mines, Tasmania, Unpublished Report 1964/05.

Matthews, W.L. 1972: Examination of proposed subdivision, East Devonport. Department of Mines, Tasmania, Technical Reports 15: 55-58.

Matthews, W.L. 1974: Examination of a landslip at St Leonards. Department of Mines, Tasmania, Technical Reports 17: 124-126.

Moon, A.T. 1984a: Bishop's simplified slope stability analysis with a Hewlett-Packard 41C calculator. Department of Mines, Tasmania, Unpublished Report 1984/51.

Moon, A.T. 1984b: Preliminary ideas on the development of guidelines for consultants undertaking slope stability assessments. Department of Mines, Tasmania, Unpublished Report 1984/56.

Nye, P.B. 1931a: Supplementary report on Grooms Slip. Department of Mines, Tasmania, Unpublished Reports 1931: 115-118.

Nye, P.B. 1931b: Report on land slips (other than that known as Grooms Slip) near Penguin and Ulverstone. Department of Mines, Tasmania, Unpublished Reports 1931: 119-121.

Nye, P.B. 1931c: Report on Grooms Slip near Penguin. Department of Mines, Tasmania, Unpublished Reports 1931: 122-126.

Schuster, R.L. \& Krizek, R.J. (eds) 1978: Landslides: analysis and control. Transportation Research Board (National Research Council) Special Report 176. National Academy of Sciences, Washington D.C.: 234 pp.

Sloane, D.J. 1979: Notes on the Aerodrome Hill landslip area Department of Mines, Tasmania, Unpublished Report $1979 / 53$.

Sloane, D.J. 1985: Landslide zoning at Beauty Point and St Helens, Tasmania. Proceedings IVth International Conference and Field Workshop on Landslides, Tokyo, August 1985. The Japan Landslide Society: 47-54.

Stevenson, P.C. 1969: A mud spring and a landslip at Deviot Department of Mines, Tasmania, Technical Reports 14: 79-82.

Stevenson, P.C. 1971a: The landslip potential of a proposed 
subdivision at Penguin. Department of Mines, Tasmania, Unpublished Report 1971/07. Stevenson, P.C. 1971b: Landslip zones - Camdale, Burnie. Department of Mines, Tasmania, Unpublished Report 1971/25.

Stevenson, P.C. 1972a: Report on a landslip at St Leonards. Department of Mines, Tasmania, Unpublished Report $1972 / 9$.

Stevenson, P.C. 1972b: The assessment of land stability at Panorama Heights subdivision, Devonport. Department of Mines, Tasmania, Unpublished Report 1972/11.

Stevenson, P.C. 1972c: Examination of a landslip at Beauty Point. Department of Mines, Tasmania, Technical Reports 15: 61-63.

Stevenson, P.C. 1974: A re-examination of Grooms Slip, near Penguin. Department of Mines, Tasmania, Technical Reports 17: $120-121$.

Stevenson, P.C. 1975a: Landslips in the Tamar Valley: an updated report on a continuing investigation. Department of Mines, Tasmania, Unpublished Report 1975/80.

Stevenson, P.C. $1975 \mathrm{~b}$ : A predictive landslip survey and its social impact. Proceedings of the Second Australia-New Zealand Conference on Geomechanics, Brisbane, 21-25 July, 1975. National Conference Publication No. 75/4. Institution of Engineers, Australia: 10-15.
Stevenson, P.C. 1978a: Guidelines for the planning of soil investigations in relation to slope stability and swelling soils. Department of Mines, Tasmania, Unpublished Report 1978/02.

Stevenson, P.C. 1978b: The evolution of a risk-zoning system for landslide areas. Department of Mines, Tasmania, Unpublished Report 1978/09.

Stevenson, P.C. 1978c: Extended definitions of the five landslide risk zones. Department of Mines, Tasmania, Unpublished Report 1978/24.

Walker, B.F. \& Fell, R. (eds) 1987: Soil slope instability and stabilisation: proceedings of an extension course, Sydney, 30 Nov.-2 Dec. 1987. A.A. Balkema, Rotterdam: 440 pp.

Weldon, B.D. 1987: SLIPCIRC - a GW-BASIC program for Bishop's simplified slip circle stability analysis on an IBM-compatible micro-computer. Department of Mines, Tasmania, Unpublished Report 1987/51.

Záruba, Q. \& Mend, V. 1969: Landslides and their control. Elsevier, Amsterdam: 205 pp.

(accepted 1 November 2011) 